\title{
Introduction: The Establishment of Eurofoods
}

Early in 1982 several members of the Department of Human Nutrition of the Agricultural University in Wageningen decided that the time had come to do something about the compatibility of food consumption tables and nutrient data banks in Europe. This idea was presented to and accepted by two groups of nutritionists and food scientists in Europe. These groups were the Working Group on Diet and Cancer of the European Organization for Cooperation in Cancer Prevention Studies (ECP) and Subgroup 4 of Cost 91 which is coordinated by the Commission of the European Communities.

In order to bring people in Europe interested in nutrient data banks together, it was decided to hold a workshop in Wageningen, May 29-31, 1983, immediately after the Fourth European Nutrition Conference held in Amsterdam. The workshop, entitled 'Towards Compatibility of Nutrient Data Banks in Europe', was designed as a first step towards: (1) increased and easier exchange of analytical data on food composition between the various countries in Europe; (2) increased opportunities for cooperation in international nutrition studies within Europe arising from increased compatibility of the nutrient data banks, and (3) increased exchange of information on the development of nutrient data banks in Europe.

An organizing committee was established with 6 representatives of various groups in The Netherlands together with 3 people from other countries in Europe. The members of

this committee were: Dr. C.E. West (coordinator), Miss W.A. van Staveren, M.Sc, Ir. B.C. Breedveld, Dr. A.B. Cramwinckel, Miss K.F.A.M. Hulshof, Ir. M.J. van Stigt Thans, Dr. L. Arab, Dr. D.A. T. Southgate, and Mrs. L. Bergström (for list of affiliations and addresses see Appendix).

When the idea of holding the workshop in Wageningen was being considered, it was thought to be somewhat of a novel development. However, it soon became obvious that other people were having the same thoughts. Within Europe, a working group on food composition tables and data banks had already been established to facilitate cooperation within the Nordic countries (Denmark, Finland, Norway and Sweden, which were later joined by Iceland). Therefore, a member of the Nordic Working Group (Mrs. L. Bergström) was invited to join the Organizating Committee. On the other side of the Atlantic in the United States, Infoods was being planned (see below). Its initial aims as outlined in the paper by Dr. Rand were 'the creation of a comprehensive, internationally focused food data base covering the spectrum of biologic activity of food from essential nutrients to non-nutrients and contaminants'. As these aims and those of the workshop in Wageningen have very much in common, it was decided to call the organization being established to run the workshop and subsequent activities, Eurofoods. The name Eurofoods was decided upon as it was felt that it expressed the idea of being closely associated with Infoods while re-

8

Introduction

taining the objective of European cooperation. (In a similar way, the Nordic working group on food composition tables and data banks has now adopted the name Norfoods.) Representatives of Infoods were invited to the Eurofoods workshop to strengthen the links between the two organizations. In fact much of the funding for the workshop came from Infoods. Funds were also 
made available by ECP, Cost 91, the University of Heidelberg, ZWO (the Dutch organization for supporting scientific research), and the Agricultural University in Wageningen. The Netherlands Nutrition Foundation acted as guarantor in case sufficient funds could not be raised from other sources.

As mentioned above, Eurofoods was being established at the same time as Infoods which held a planning meeting in Bellagio, Italy in 1983 attended by a number of people associated with Eurofoods. The basic aims of Infoods are to promote international participation and cooperation in the acquisition and exchange of data on the nutrient composition of foods in forms appropriate to the needs of a wide range of people and organizations. At the Eurofoods Workshop in Wageningen, it was firmly established that Eurofoods will work both independently and within the framework of Infoods. In following

the recommendations made at the workshop, it can play an important part in reaching the goals established by Infoods. In order to achieve its aims, Infoods has established a number of task forces including the task force on the revision of the guidelines on the preparation of food composition tables. The earlier guidelines were prepared by Dr. South-gate, and he is revising them with the assistance of Dr. Heather Greenfield of the School of Food Technology of the University of New South Wales in Sydney, Australia.

Infoods gave assistance to Eurofoods in running the Wageningen workshop and has been instrumental in setting up Noafoods in North America, Latinfoods in Latin America, and Asiafoods in Asia. The coordinator of Eurofoods is on the Policy Committee of Infoods which met in Miami in August 1983 and in Madrid in July 1984. Other members of Eurofoods, in addition to Dr. Southgate, have been appointed to Infoods task forces. In this way duplication of work will be avoided.

In the same way that Eurofoods works with Infoods, a close relationship has been built up between Norfoods and Eurofoods. There is no conflict of interest between the Nordic Working Group and Eurofoods, and each can benefit from the existence of the other. 